\title{
ADCP, MULTI-FREQUENCY ANALYSIS FOR FLOW MEASUREMENTS IN RIVERS
}

\author{
Gastón Priego-Hernández, Héctor Rubio-Arias, Fabian Rivera-Trejo \\ Juarez Autonomous University of Tabasco, Academic Division of Engineering and Architecture, Cunduacan, Tabasco, Mexico
}

\begin{abstract}
Aim of the study

Recently, the use of acoustic Doppler current profilers (ADCP) gains in popularity. Considering the use of various equipment, a question arises whether there are any differences in measuring with ADCP that works at different frequencies. The aim of this study was to compare and evaluate three ADCPs operating at different frequencies: 2,000 kHz, 1,500 kHz, and $600 \mathrm{kHz}$ under field conditions.
\end{abstract}

\section{Material and methods}

Following parameters were applied for a transverse section of $100 \mathrm{~m}$ in width and $7 \mathrm{~m}$ in depth: (1) components of velocity flow, (2) depth, (3) transverse distance among vectors, (4) total distance and (5) geographic position of each vector.

\section{Results and conclusions}

The results showed that velocity magnitudes were low in margin areas, while high in the center. In comparison with other devices the $2,000 \mathrm{kHz}$ ADCP keeps a homogeneous velocity distribution up to $5.0 \mathrm{~m}$ in depth. Also, the statistical and graphic analysis demonstrated that flow measurements did not differ by more than $5 \%$. Nevertheless, the review of velocities showed significant differences between ADCPs. High frequency means more detailed data, but less deep range, particularity in zones with upper sediments concentration. Low frequency means less detailed data, but deeper range. Furthermore, our findings suggest that measurements performed in rivers provide results, which sometimes are entirely different from results obtained in laboratory.

Keywords: ADCP, depth measurement, river discharge, hydrodynamic, acoustic techniques

\section{INTRODUCTION}

Acoustic devices have become increasingly popular due to their efficiency, rapidity, and quality in flow measurement (Rennie et al., 2002; Muste et al., 2003; Winterwerp et al., 2006; Priego-Hernandez and Rivera-Trejo, 2016). They can measure velocity fields in three directions (3D) as well as quantifying sediment transport in suspension (Stone and Hotchkiss, 2007; Czuba et al., 2011; Thorne and Hurther, 2014;
Ehrbar et al., 2017). Time is one of the advantages of applying the ADCP measures, since processes that require one or two hours with mechanical current meter are done with ADCP in 15 minutes on average. However, that they not easy to use and operators require training in configuration, measurement techniques, and data processing. Another disadvantage is the cost, which is approximately 15 times as much as Pricetype current meters and four times as much as hydrometric current meters. A lot of research is developed

『e-mail: jgfabianrivera@gmail.com 
in laboratories, under controlled conditions (Shih et al., 2000; Mueller et al., 2007; Venditti et al., 2016); however, we were interested in testing ADCPs under field conditions. ADCPs work at high or low frequencies, and even with a combination of both. Frequency plays a crucial role in measuring, determining the scope and penetration of the acoustic pulse in the water column. The attenuation of the acoustic signal is proportional to the frequency, which is more significant for high frequencies than for low ones. High frequency implies smaller measurement cells, with lower penetration range (a few meters); low frequency involves bigger measurement cells, with greater penetration range (tens or even hundreds of meters). ADCPs cannot measure velocities in near-bed zones, because acoustic beams make contact with beds at oblique angles and reflect in different directions without returning to the transducer (Simpson, 2001). The same effect occurs in riverbanks; thus, to estimate the velocities, an interpolation method is employed (Fulford and Sauer, 1986). Even with equipment working at different frequencies, it is possible to measure the same depth range. Nonetheless, the differences that may be found between these measurements are not evident. Therefore, we compared three Doppler devices that operate at the following frequencies: (I) $2,000 \mathrm{kHz}$, (II) $1,500 \mathrm{kHz}$, and (III) $600 \mathrm{kHz}$. These results can be advantageous to research groups, which have limited resources and need to acquire one ADCP (Tauro et al., 2018).

\section{MATERIALS AND METHODS}

\section{Background on the equipment}

ADCP's transducers have blanking zone and side-lobe interference (see: Fig. 1a), which is a limit determinating the minimum measurement depth. The blanking distance is the time elapsed during a transmission of acoustic pulse from and back to a transducer. The sidelobe is the noise signals reflected by the bed's bottom and overlapped by the primary return signal (Gordon, 1989). The equipment software performs this task automatically, taking the first valid vertical measurement by ADCP and the distance from the vessel to the shore to estimate areas in the margins (see: Fig. 1b). The software calculates the discharge in these zones by interpolation (Fulford and Sauer, 1986).

\section{ADCP operating principles}

ADCP generally have three or four monostatic transducers (Sontek, 2007; Teledyne, 2014). Every transducer generates a sonic beam and uses ultrasound - greater than $25 \mathrm{kHz}$ - to measure the velocity of sediment particles in suspension. When the energy of sound waves goes through the particles traveling in suspension, it makes them vibrate and transmit acous-

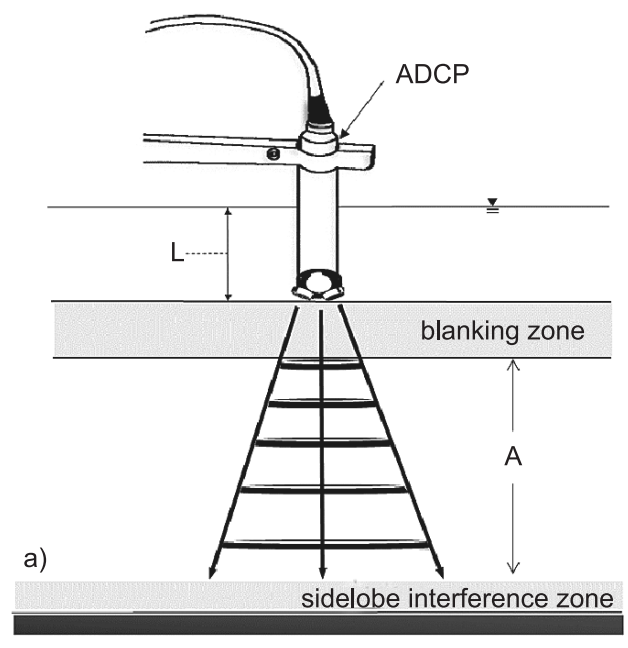

$\mathrm{L}$, transducer length; A, measuring area

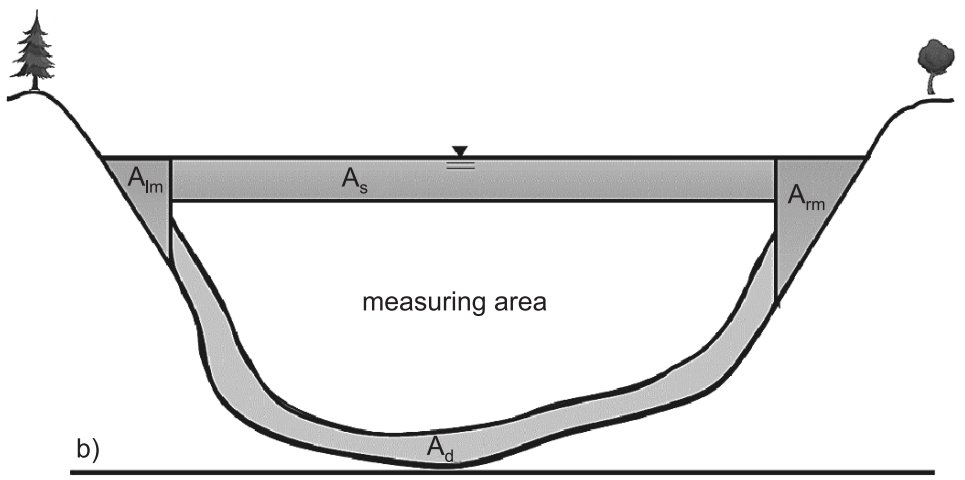

$A_{l m}$, estimated area left margin; $A_{r m}$, estimated area right margin;

$A_{s}$, estimated area surface; $A_{d}$, estimated area depth

Fig. 1. Measurement zones: (a) blind ADCP zones and (b) areas estimated by interpolation methods 
tic energy from one particle to adjacent ones. With frequencies higher than $25 \mathrm{kHz}$, vibration remains stationary, which allows for measuring flow velocity (Vogt and Neubauer, 1976). ADCP's transducers generated a velocity profiles measured for a column of water, divided into cells. Each cell center represents an average magnitude of the velocity vector. High frequency will have a smaller blanking area than low frequency.

\section{Study area}

We tried to measure over the confluence Grijalva River - Carrizal located in Tabasco, Mexico. However, one branch - Grijalva River - was more profound than the other and stayed out of range of the $2000 \mathrm{kHz}$ ADCP. Then, we only used data from the Carrizal River. The study took place in flood season (September - January). The Carrizal River is at WGS84 18.007042, -92.893362 (see: Fig. 2). The classification of Carrizal River is as a subcritical regime - plan river - with a mean slope of $0.00031 \mathrm{~m}$, $350 \mathrm{~m}^{3} \cdot \mathrm{s}^{-1}$ of annual average flow and maximun anual flood of $1.466 \mathrm{~m}^{3} \cdot \mathrm{s}^{-1}$ (Rivera-Trejo et al., 2010). It is considered a sandy and sinuous river (sinuosity
$=1.27)$. The importance of this zone is due to the upstream located in Villahermosa City, Tabasco's state capital. This city is susceptible to floodings, and this river is being monitored very often to evaluate its fluvial behavior.

\section{Data collection}

Measurements were taken with three ADCPs working at three differences frequencies: (I) $2,000 \mathrm{kHz}$, (II) $1,500 \mathrm{kHz}$, and (III) $600 \mathrm{kHz}$. Table 1. shows the main characteristics of each device. The cross-section is approximately $100 \mathrm{~m}$ wide and $7 \mathrm{~m}$ deep. Five passes test were performed at the measuring zone to obtain an average flow rate. Because Carrizal River is one of the most importent rivers in the State, it has a high fluvial traffic. Therefore, the ADCP mounted over a boat had to be used (see: Fig. 3a). This technique method is very common in field measurements and involves some changes in the trajectories (see: Fig. 3b).

To ensure that every ADCP measured velocity vectors in the right direction, calibration tests had been made for the inner compass of each device (heading, pitch, and roll). The magnetic North Pole was used instead of the geographic North Pole. The British

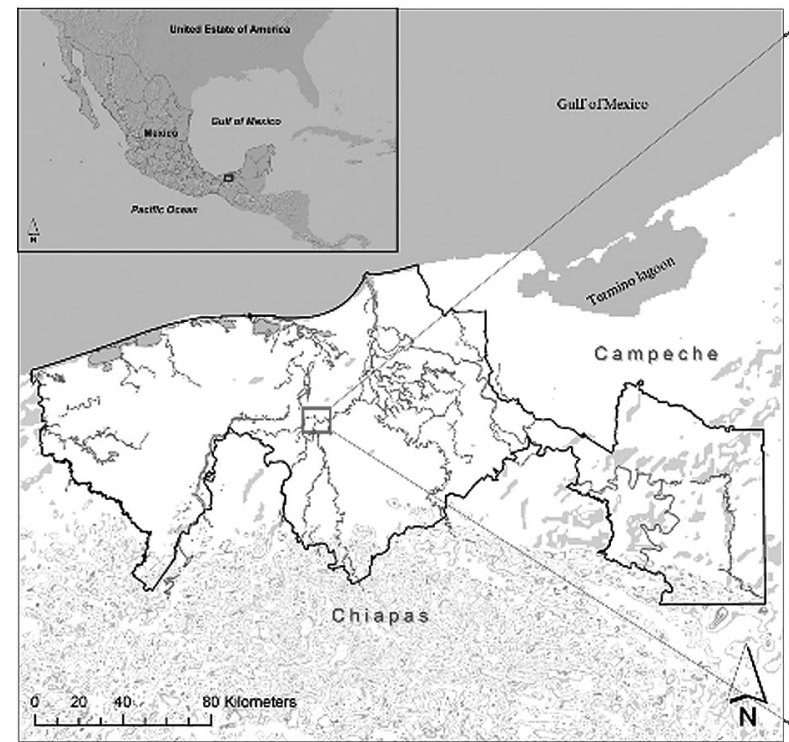

a)

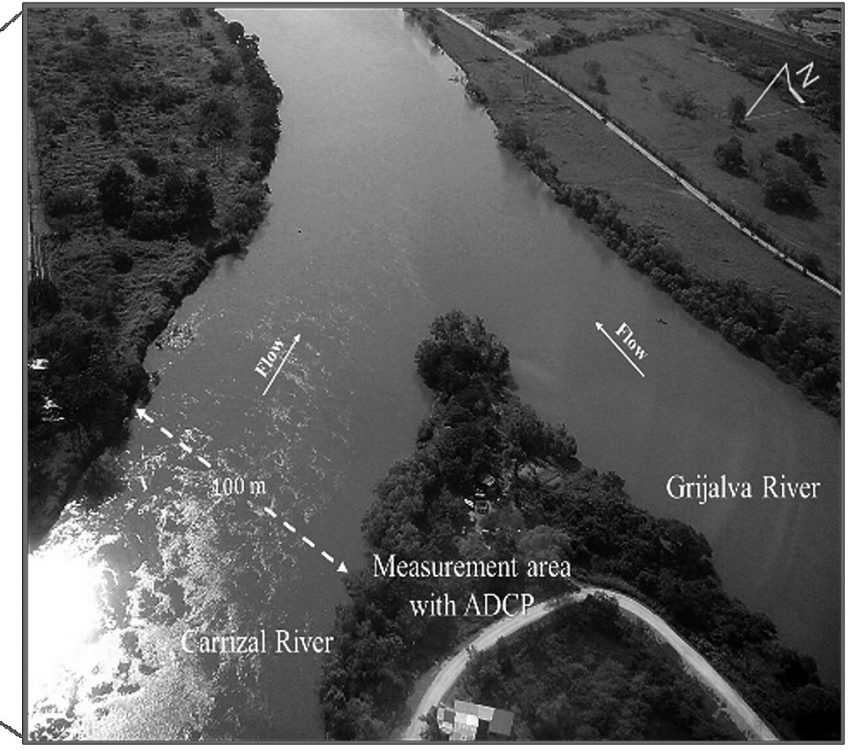

b)

Fig. 2. a) Map of the Carrizal River in Tabasco, Mexico and b) the field survey points overlapped on a georeferenced image of the study area 


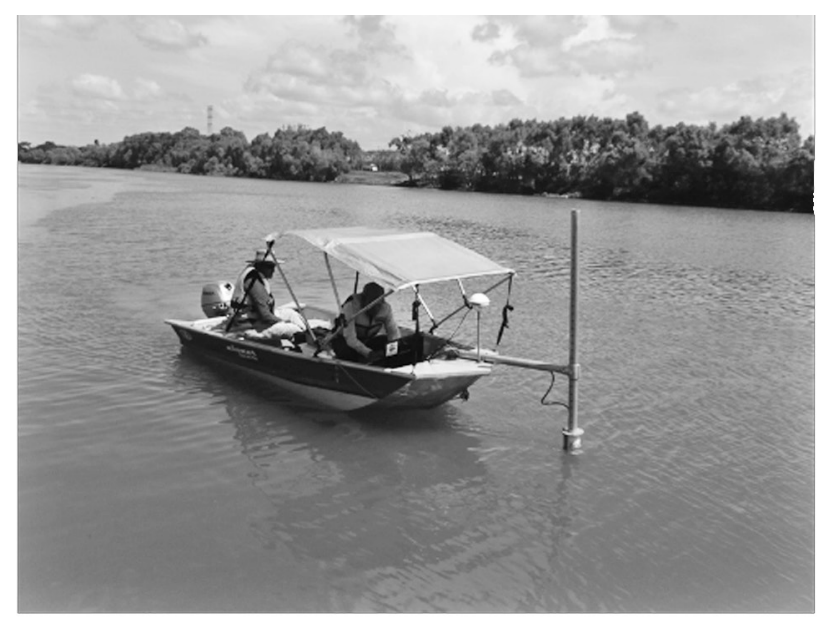

a)

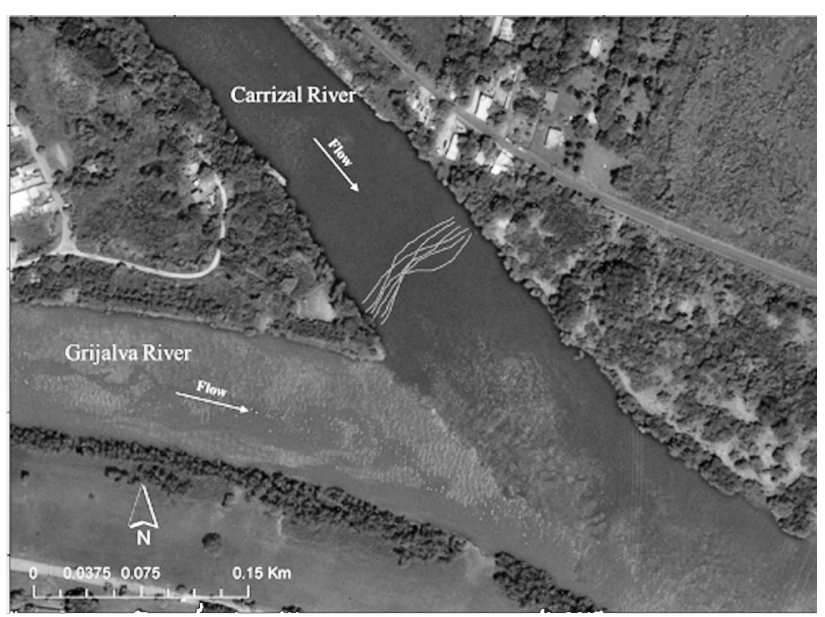

b)

Fig 3. (a) ADCP mounted over a boat; (b) Measurements trajectories

Geological Survey (BGS, 2015) allows the correct magnetic declination value specific for the area to be measured using a geographic point for each zone. Data measured by every ADCP on the cross section were analyzed with vendor software programs, RiverSurveyor ${ }^{\circledR}$ and Winriver II ${ }^{\circledR}$. Also, a custom Excel sheet was built to get hydrodynamics and velocity profiles. The hydrodynamic data parameters were: the magnitude of the velocity vector, velocities in the bed section and velocity vertical profile. The equipment cell sizes were: $0.20 \mathrm{~m}$, for $2,000 \mathrm{kHz} ; 0.50 \mathrm{~m}$, for $1,500 \mathrm{kHz}$; and for $600 \mathrm{kHz}$, the equipment does not allow manual configuration, it had a self-configuration of $0.10 \mathrm{~m}$ in the first five cells and $0.40 \mathrm{~m}$ in the remaining ones.

Table 1. ADCP's characteristic

\begin{tabular}{lccc}
\hline Model & $\begin{array}{c}\text { StreamPro } \\
\text { (Teledyne) }\end{array}$ & $\begin{array}{c}\text { RiverCat } \\
\text { (Sontek) }\end{array}$ & $\begin{array}{c}\text { RiverRay } \\
\text { (Teledyne) }\end{array}$ \\
\hline Frequency & $2000 \mathrm{kHz}$ & $1500 \mathrm{kHz}$ & $600 \mathrm{kHz}$ \\
\hline Beam Angle & $20^{\circ}$ & $25^{\circ}$ & $30^{\circ}$ \\
\hline $\begin{array}{l}\text { Operating } \\
\text { range }\end{array}$ & $0.20-7.0 \mathrm{~m}$ & $0.90-30 \mathrm{~m}$ & $0.40-60 \mathrm{~m}$ \\
\hline Cell size & $0.02-0.20 \mathrm{~m}$ & $0.25-4.0 \mathrm{~m}$ & $\begin{array}{c}\text { Automatic } \\
\text { selection* }\end{array}$ \\
\hline Blanking & $0.03 \mathrm{~m}$ & $0.40 \mathrm{~m}$ & $0.25 \mathrm{~m}$ \\
\hline
\end{tabular}

*.10 m minimum.

\section{Backscatter intensity}

The acoustic energy (in $\mathrm{dB}$ ) returned from scattered particles. Greater intensity means higher load of suspended sediment. Equations to get intensities to use a sonar equation according to the characteristics of each acoustic device are following:

For $2000 \mathrm{kHz}$ and $600 \mathrm{kHz}$ (Dinehart and Burau, 2005),

$$
B I=\mathrm{EIS} \times[\text { counts }]+20 \log \mathrm{R}+20 \alpha \mathrm{R}
$$

Where: EIS (echo intensity scale $)=123 /(\mathrm{Te}+273)$ in $\mathrm{dB} /$ caints, $\mathrm{Te}$ is electronics temperature recorded near the ADCP transducer, $\mathrm{R}$ is the distance to the ensonified volume, in meters, and $\alpha$ is the sand and absorption coefficient.

For 1500 kHz (SonTek, 1997),

$$
B I=(-20+C) \times \log 10\left(\frac{D}{\cos \theta}\right)-2 \alpha\left(\frac{D}{\cos \theta}\right)
$$

where: $c=20 \times h / h-0.5)$ is the measure of stratification in the water column, $h / h$ is the ratio of the depth of the epilimnion to the total depth of the water column, $D$ is the vertical range form the system, in meters, $\theta$ is transducer beam mounting angle and $\alpha$ is sand absorption coefficient.

We converted collected data to decibels $[\mathrm{dB}]$ according to Eqs. (1) and (2) 


\section{RESULTS}

\section{Backscatter intensity and magnitude of velocity vectors}

Figure 4 a shows the backscatter intensity measured by each ADCP. In each graph, the intensity $(\mathrm{dB})$ is related to the quality of the velocity's measurements, and it depends on the number of particles traveling together with the water. This parameter is related to the dispersion energy called signal-to-noise (NSR).

The differences between charts result from the fact that measurements were taken at different points in time and with various suspension sediment loads. Figure
$4 \mathrm{~b}$ shows the magnitudes of the velocity vectors. The lowest velocities (blue) were at sides of the section and the highest (red) at the center. The near-bed velocities (blank zone) were interpolated by the software.

\section{Flow velocity}

Figure 5a shows the mean backscatter intensity in the cross-section. Differences between each ADCP measurement are due to the instantaneous immediate natural conditions and the blanking zone. Figure $5 \mathrm{~b}$ shows the mean velocities. Although curves have the same behavior, measurements are more representative for the $2,000 \mathrm{kHz}$ and $600 \mathrm{kHz}$ ADCPs. While there were
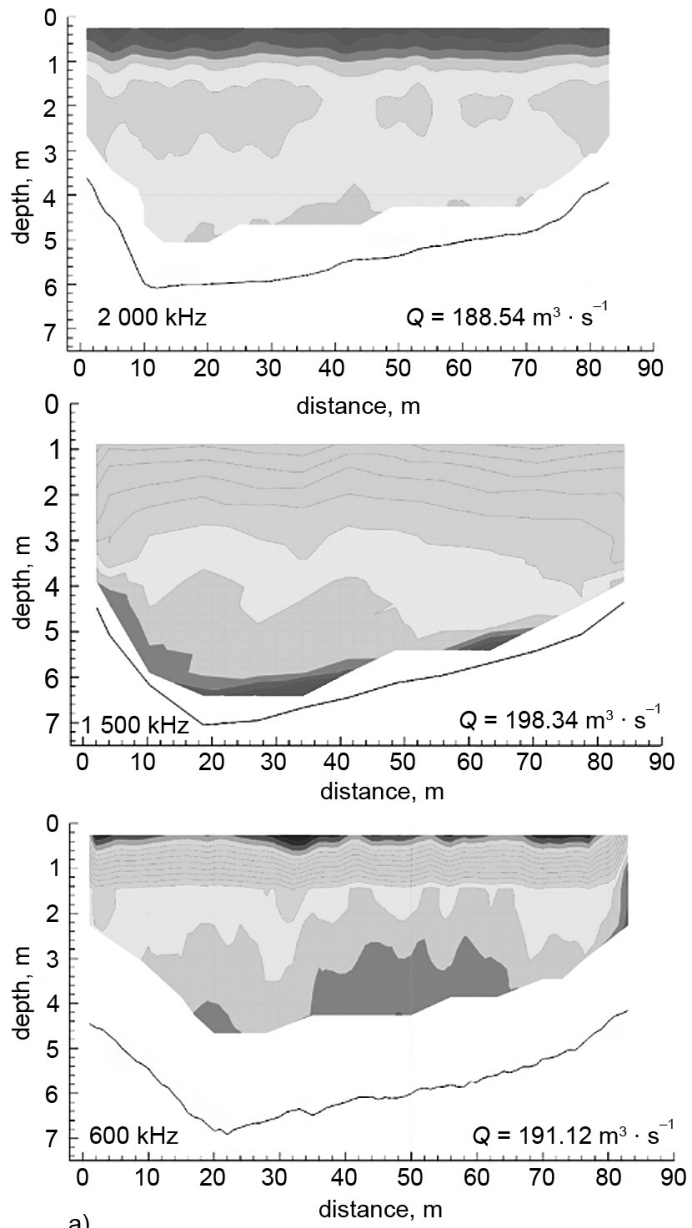
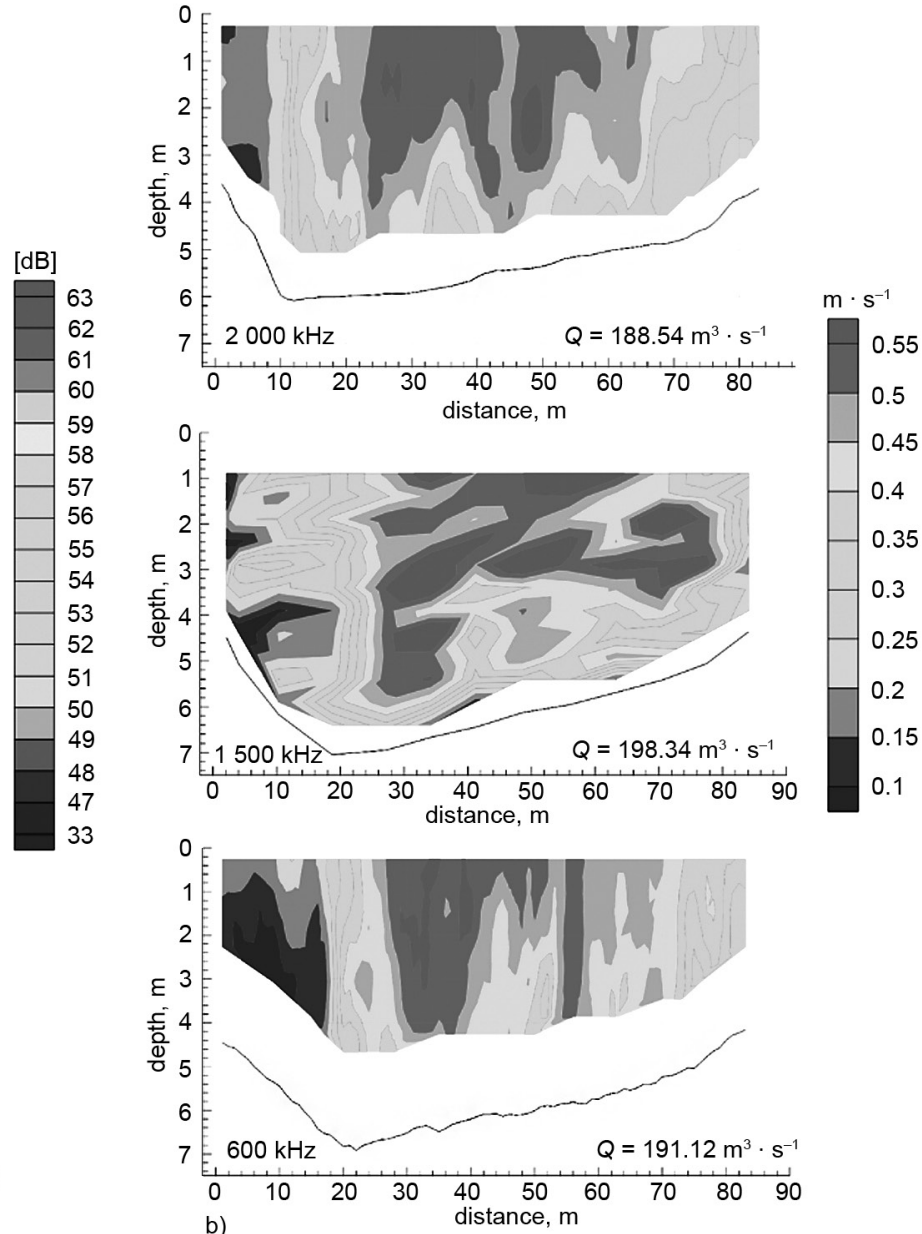

Fig. 4. (a) Backscatter intensity in the cross section and (b) Magnitude of velocity vectors in the cross section 

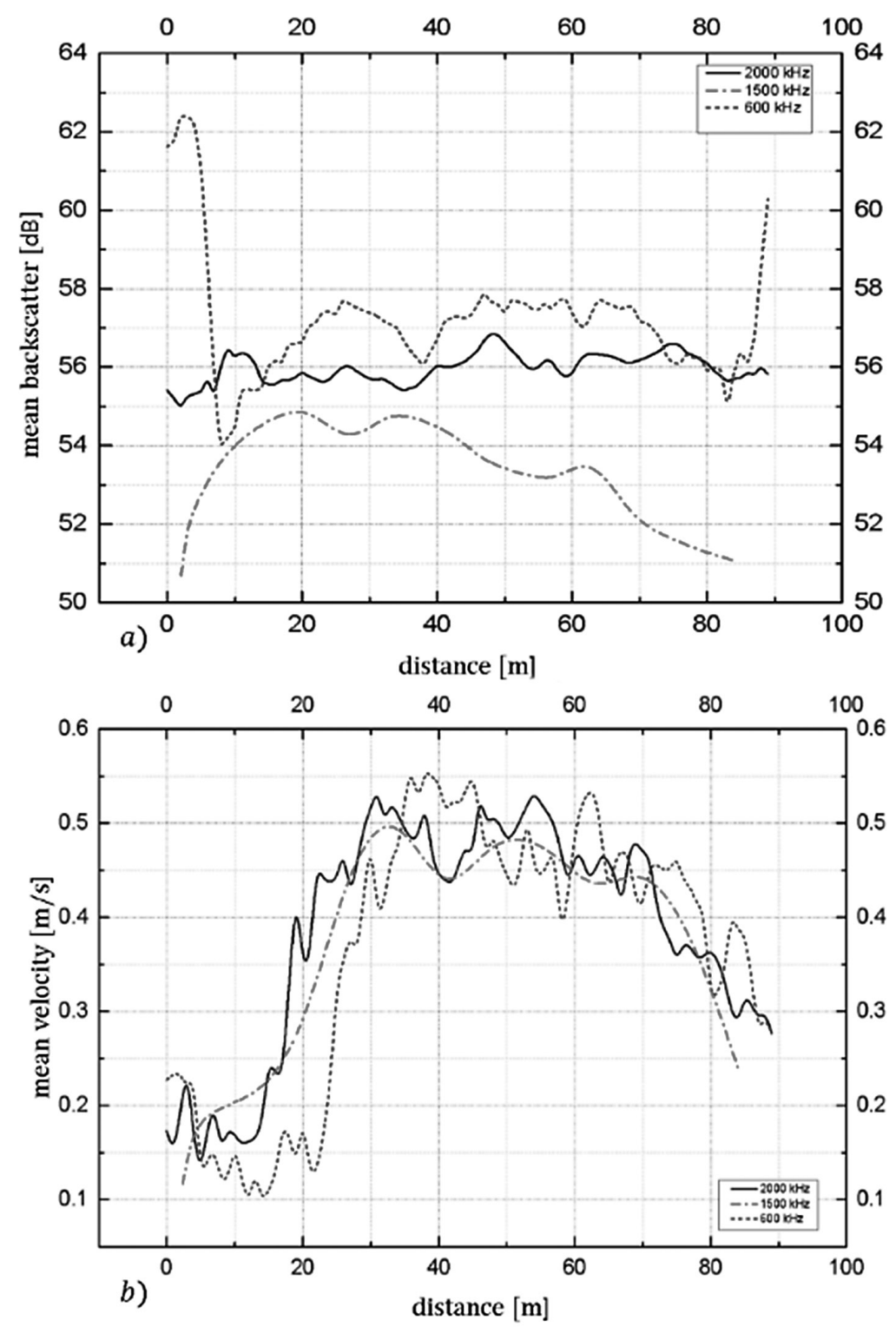

Fig 5. (a) Mean backscatter intensity measured in the cross section and (b) Mean velocity measure

11 measurements realized for $1,500 \mathrm{kHz}, \mathrm{ADCP}$ only did three. That is because the $1,500 \mathrm{kHz}$ ADCP needs $5 \mathrm{~s}$ between each measurement, and the other two take approximately $1.40 \mathrm{~s}$. Velocity profiles of a cross-section are essential, because they allow to determinate the tangential stresses of the river bottom, Manning roughness coefficients, and sediment transport.
Figure 6 shows the number of cells in the vertical axis at a depth of $5 \mathrm{~m}$. ADCP for $2,000 \mathrm{kHz}$ provides more detailed distribution of velocity than the other two devices (see: Fig. 6a). In Figure 6b, the $1,500 \mathrm{kHz}$ ADCP delivers a low level of detail of the velocity profile and, as is observed, the measurements start at approximately $0.90 \mathrm{~m}$. The $600 \mathrm{kHz}$ ADCP (see: 


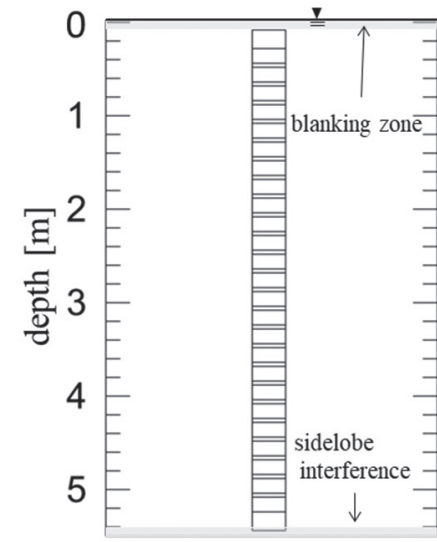

a) $2,000 \mathrm{kHz}$

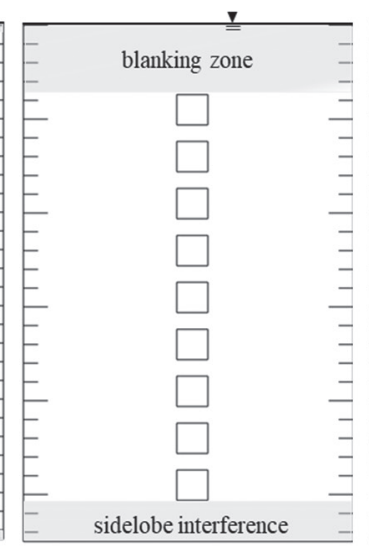

b) $1,500 \mathrm{kHz}$

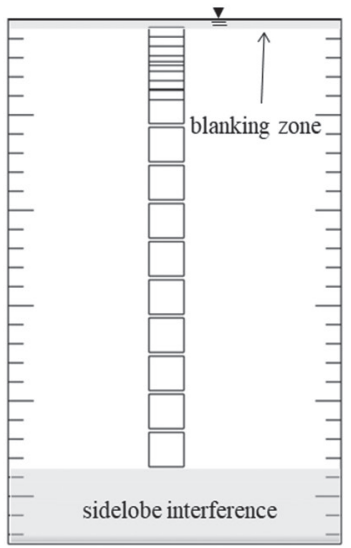

c) $600 \mathrm{kHz}$

Fig 6. Velocity profiles for $5 \mathrm{~m}$ depth measured by the three ADCPs

Fig. 6c), provides more detail in the first $0.50 \mathrm{~m}$. , but then the appreciation of velocity vectors decreases because of the size of its cells.

\section{Flow rate}

Table 2 shows the flow rate measurements in the section at a specific time. The standard deviation associated with the flow rate recorded by the $2,000 \mathrm{kHz}$ ADCP showed a relatively small variation between measurements, when compared to the flow rate registered by the $1,500 \mathrm{kHz}$ device, which shows a significant standard deviation. It implies that more measurements must be made to obtain a more representative flow rate. As well, the discharge measured with different ADCPs was not more than $5 \%$. This indicates that for current measurements all the equipment can be used independent of the operating frequency, as long as it is within the device's measuring range. Table 3 shows that the $2,000 \mathrm{kHz}$ ADCP has the highest number of cells per unit of area unit, because of the cell size of $0.20 \mathrm{~m}$ and the electronics adjustment time is short $(1.40 \mathrm{~s})$. The $1,500 \mathrm{kHz}$ ADCP cell size is $0.50 \mathrm{~m}$ and it has a lower number of cells per unit of area, with the electronic adjustments approximately $4.57 \mathrm{~s}$, which implies that the transducer software interpolates data, where the ADCP cannot measure, increasing measurement errors. Hydrodynamics (velocity fields) needs greater operating frequencies to get more detailed data. Having a good representation of velocity fields is essential to determine transverse or secondary velocities, as well as the relationship of velocity and the quantity of transported

Table 2. Average flow rate on the cross section under study

\begin{tabular}{ccccccccc}
\hline & $2000 \mathrm{kHz}$ & \multicolumn{9}{c}{$1500 \mathrm{kHz}$} & \multicolumn{3}{c}{$600 \mathrm{kHz}$} \\
\hline $\begin{array}{c}\mathrm{Q} \\
\mathrm{m}^{3} \cdot \mathrm{s}^{-1}\end{array}$ & $\begin{array}{c}\hat{\mathrm{Q}} \\
\mathrm{m}^{3} \cdot \mathrm{s}^{-1}\end{array}$ & $\begin{array}{c}\mathrm{Q}_{\sigma} \\
\mathrm{m}^{3} \cdot \mathrm{s}^{-1}\end{array}$ & $\begin{array}{c}\mathrm{Q} \\
\mathrm{m}^{3} \cdot \mathrm{s}^{-1}\end{array}$ & $\begin{array}{c}\hat{\mathrm{Q}} \\
\mathrm{m}^{3} \cdot \mathrm{s}^{-1}\end{array}$ & $\begin{array}{c}\mathrm{Q}_{\sigma} \\
\mathrm{m}^{3} \cdot \mathrm{s}^{-1}\end{array}$ & $\begin{array}{c}\mathrm{Q} \\
\mathrm{m}^{3} \cdot \mathrm{s}^{-1}\end{array}$ & $\begin{array}{c}\hat{\mathrm{Q}} \\
\mathrm{m}^{3} \cdot \mathrm{s}^{-1}\end{array}$ & $\begin{array}{c}\mathrm{Q}_{\sigma} \\
\mathrm{m}^{3} \cdot \mathrm{s}^{-1}\end{array}$ \\
\hline 189.17 & & & 204.73 & & & 188.84 & & \\
188.54 & & & 192.4 & & & 198.46 & & \\
189.77 & 189.15 & 0.49 & 191.61 & 197.20 & 4.80 & 187.73 & 191.85 & 3.79 \\
188.66 & & & 198.93 & & & 193.11 & & \\
189.64 & & & 198.34 & & & 191.11 & & \\
\hline
\end{tabular}

$\mathrm{Q}$, flow rate; $\hat{\mathrm{Q}}$, average flow rate; $\hat{\mathrm{Q}}_{\sigma}$, average flow rate for the standard deviation. 
sediment. When trying to characterize secondary velocities, a higher number of profiles are sought in the measurement of the cross-section of the river in order to observe velocity trends. To estimate the concentration of sediments in suspension, it is essential to obtain a more detailed velocity profile in the water column, in particular in the prompt sampling by mechanical means. Although the $600 \mathrm{kHz}$ ADCP has a more significant number of profiles, the 2,000 kHz ADCP allows detailed resolution of velocity vectors (see: Fig. 5a).

Nevertheless, in deep zones and where the velocities and transportation of sediments are greater, ADCPs with frequencies higher than $2,000 \mathrm{kHz}$ have measurement problems, because the wavelength is small and losses acoustic energy by absorption of the return beam by sediments in suspension and the signal may be lost. Profilers with low frequencies under such conditions have more possibilities of measuring. Nevertheless, as the cell size is higher, a smaller amount of data is generated.

Table 3. Comparison of flow rate obtained with the different ADCPs in the cross-section under study.

\begin{tabular}{ccccccc}
\hline ADCP & $\begin{array}{c}\mathrm{CS} \\
\mathrm{m}\end{array}$ & $\begin{array}{c}\hat{\mathrm{B}} \\
\mathrm{m}\end{array}$ & $\begin{array}{c}\hat{\mathrm{A}} \\
\mathrm{m}^{2}\end{array}$ & $\hat{\mathrm{C}}$ & $\begin{array}{c}\hat{\mathrm{V}} \\
\mathrm{m}^{3} \cdot \mathrm{s}^{-1}\end{array}$ & $\begin{array}{c}\hat{\mathrm{Q}} \\
\mathrm{m}^{3} \cdot \mathrm{s}^{-1}\end{array}$ \\
\hline $2000 \mathrm{kHz}$ & 0.20 & 97.66 & 528.49 & 2045.44 & 0.357 & 189.15 \\
$1500 \mathrm{kHz}$ & 0.50 & 89.04 & 488.05 & 166.62 & 0.402 & 197.20 \\
$600 \mathrm{kHz}$ & 0.40 & 92.86 & 503.17 & 1663.45 & 0.382 & 191.85 \\
\hline
\end{tabular}

CS, cell size; $\hat{B}$, average width; $\hat{A}$, average area; $\hat{C}$, average number of cells in section;

$\hat{\mathrm{V}}$, average velocity; $\mathrm{Q}$, average flow rate.

\section{DISCUSSION}

It was found that discharge measurements do not differ from each other more than 5\% (see: Table 3 ). These results are in agreement with Gordon (1989) and Mueller (2002). We used the measurements from $2,000 \mathrm{kHz}$ $\mathrm{ADCP}$ as baseline, because the highest frequency reduces the velocity uncertainty (Eq. 3), although has a diminution in-depth range.

$$
\sigma=\frac{1.6 \times 10^{5}}{F D\left(N^{\frac{1}{2}}\right)}
$$

where $\sigma$ the standard deviation $\left[\mathrm{m}^{3} \cdot \mathrm{s}^{-1}\right]$; the frequency $[\mathrm{Hz}]$; the depth cell size $[\mathrm{m}]$; and $\mathrm{N}$ the number of pings averaged together to obtain the velocity estimate. The constant $1.6 \times 10^{5}$ has dimensions $\left[\mathrm{m}^{2} \cdot \mathrm{s}^{-2}\right]$.

Our results of backscatter intensity and velocity (see: Fig. 4a and 4b) showed differences because the measurements were taken under field conditions. Nevertheless, the three ADCPs measured the same intensity at a depth between 1 and $2 \mathrm{~m}$ into the cross section (see: Fig. 4a). The intensities taken from the $2000 \mathrm{kHz}$ ADCP as a reference and graph for the others ADCPs intensities (see: Fig. 7) showed that for the range between 1 to $2 \mathrm{~m}$ they are similar and the differences among them depended on the blanking zone and the side-lobe interference. In the case of depth zones these variations decrease, because the blanking zone and side-lobe interference are smaller with respect to the total depth. compared against the depth, by example $20 \mathrm{~m}$.

However, the three ADCPs display high velocities in the center of the river. These results are typical, because the section is straight and in a fixed river location (Riley and Rhoads, 2011; Baranya et al., 2015).

In the case of velocity profiles along the stream's cross section (see: Fig. 8), the best distribution was obtained with the $2000 \mathrm{kHz}$ ADCP (see: Fig. 8a). It happened because the cell sizes were the smallest in the vertical and horizontal scales. These results con-

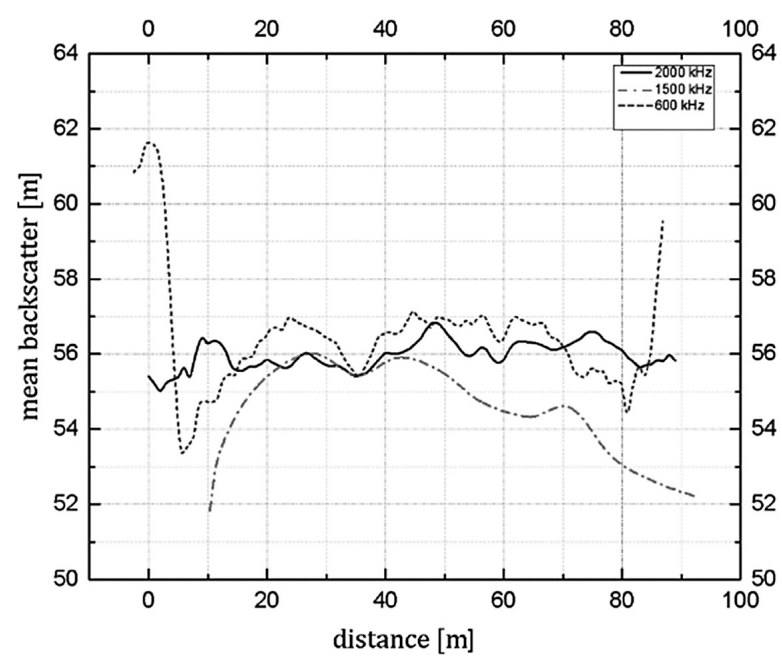

Fig 7. Mean backscatter intensity measured in the cross section 
Rivera-Trejo, F., Priego-Hernández, G., Rubio-Arias, H. (2019). ADCP, Multi-frequency analysis for flow measurements in rivers. Acta Sci. Pol., Formatio Circumiectus, 18(1), 101-112. DOI: http://dx.doi.org/10.15576/ASP.FC/2019.18.1.101
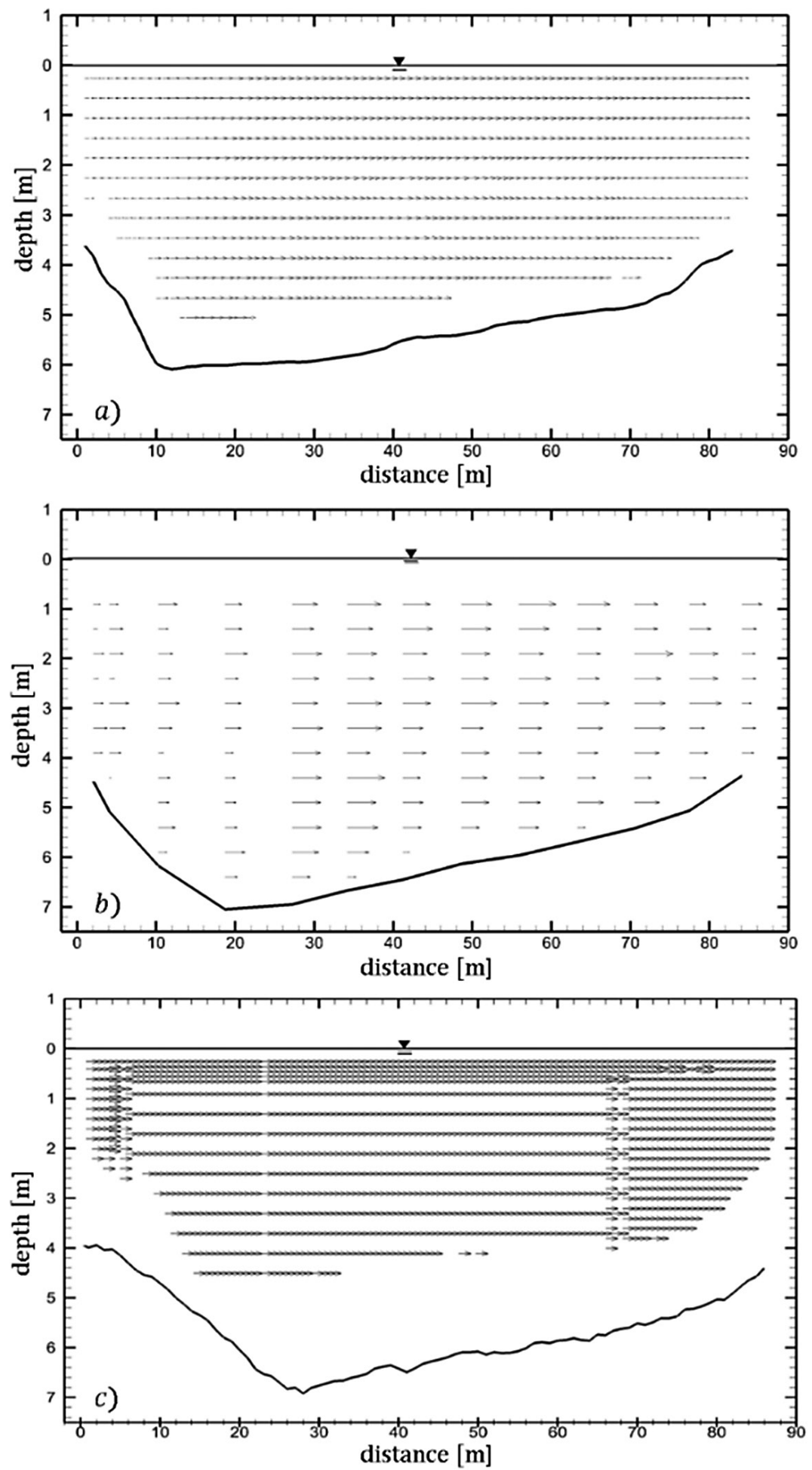

Fig. 8. Velocity profiles in a cross section: (a) $2000 \mathrm{kHz}$, (b) $1500 \mathrm{kHz}$ and (c) $600 \mathrm{kHz}$ 
trast with those obtained with the $1500 \mathrm{kHz}$ ADCP (see: Fig. 8b) and the $600 \mathrm{kHz}$ ADCP (see: Fig. 8c), in spite of fewer and more measurements points respectively, their velocity profiles distributions were not better. Szupiany et al. (2009) and Baranya et al. (2015) suggested that if you have a homogeneous distribution of velocity profiles, you get more detail in the visualization of transverse and secondary currents. The visual inspection showed that the best distribution was reached with the $2,000 \mathrm{kHz}$ ADCP.

\section{CONCLUSIONS}

The velocity quantification under natural conditions by applying ADCP is desirable given the efficacy and quickness of measurement. The comparisons of data obtained from the three ADCPs showed that frequency is fundamental for making the decision, which device to use. The ADCP with the highest frequency allows for getting the finest cell size, but has measurement problems in zones with high turbulence and great sediment transport. In flow discharge and the velocity field, all of the devices are adequate, as long as they operate in their range. The variation among the ADCP trajectory from one margin to another is the limitation for field measurements. The different paths obtained were a consequence of the velocities of water dragging the boat toward the downstream of the motion of natural current. High frequency provides more detailed data, but less deep range, particularity in zones with upper sediments concentration. Low frequency means less detailed data, but deeper range. Furthermore, our findings suggest that measurements from a river produced results, which could be entirely different from these in laboratory.

\section{ACKNOWLEDGMENTS}

Supporting data may be obtained from G.A. Priego-Hernández (email: gaston.priego@ujat.mx).

The authors thank the National Water Commission (CONAGUA) for the lease of Doppler acoustic equipment.

This research was developed in the framework of the CB-2011-1660168 Basic Science project funded by CONACYT.

\section{REFERENCES}

Baranya, S., Olsen, N.R.B., Józsa, J., (2015). Flow analysis of a river confluence with field measurements and RANS model with nested grid approach. River Research and Applications, 31(1), 28-41.

BGS, (online). World Magnetic Model (2015) Calculator, http://www.geomag.bgs.ac.uk/data_service/models compass/wmm_calc.html. [Accessed: 15 January 2015].

Czuba, J. A., Best, J. L., Oberg, K. A., Parsons, D. R., Jackson, P. R., Garcia, M. H., and Ashmore, P., (2011). Bed morphology, flow structure, and sediment transport at the outlet of Lake Huron and in the upper St. Clair River. Journal of Great Lakes Research, 37(3), 480-493.

Dinehart, R. L., Burau, J. R., (2005). Averaged indicators of secondary flow in repeated acoustic Doppler current profiler crossings of bends, Water Resour. Res., 41, W09405, DOI:10.1029/2005WR004050.

Ehrbar, D., Schmocker, L., Vetsch, D., Boes, R., and Doering, M., (2017). Measuring suspended sediments in periglacial reservoirs using water samples, LISST and ADCP. International Journal of River Basin Management, DOI: 10.1080/15715124.2017.1327866

Fulford, J.M., Sauer, V.B., (1986). Comparison of velocity interpolation methods for computing open-channel discharge in S.Y. Subitsky (ed.) Selected papers in the hydrologic sciences: U.S. Geological Survey Water-Supply Paper 2290, 154.

Gordon, R. L., (1989). Acoustic measurement of river discharge. Journal of Hydraulic Engineering, 115(7), 925-936.

Mueller D.S., (2002). Field assessment of acoustic Doppler based discharge measurements. Proceedings, Hydraulic Measurements and Experimental Methods 2002 (CD -ROM), ASCE, Reston, Va.

Mueller, D. S., Abad, J. D., Garcia, C. M., Gartner, J. W., Garcia, M. H., Oberg, K. A., (2007). Errors in acoustic Doppler profiler velocity measurements caused by flow disturbance. Journal of Hydraulic Engineering, 133(12), 1411-1420.

Muste, M., Yu, K., Spasojevic, M., (2003). Practical aspects of ADCP data use for quantification of mean river flow characteristics; Part I: moving-vessel measurements. Flow Measurement and Instrumentation 15 (2004), $1-16$.

Priego-Hernandez, G., Rivera-Trejo, F., (2016). Secondary currents: Measurement and analysis. Atmosfera 29(1), 23-34. 
Rennie, C. D., Millar, R. G., Church, M. A., (2002). Measurement of bed load velocity using an acoustic Doppler current profiler. Journal of Hydraulic Engineering, 128(5), 473-483.

Riley J.D., Rhoads B.L., 2011. Flow structure and channel morphology at a natural confluent meander bend. Geomorphology, DOI:10.1016/j.geomorph.2011.06.011.

Rivera-Trejo, F., Soto-Cortés, G., Méndez-Antonio, B., 2010. The 2007 flood in Tabasco, Mexico: An integral analysis of a devastating phenomenon. Int. J. River Basin Manag. https://doi.org/10.1080/15715124.2010.508746

Shih, H. H., Payton, C., Sprenke, J., Mero, T., (2000). Towing basin speed calibration of acoustic Doppler current profiling instruments. Proc., 2000 Joint Conf. on Water Resources Engineering and Water Resources Planning and Management, ASCE, Reston, Va, 1-10.

Simpson, M.R., (2001). Discharge measurement using an acoustic Doppler current profiler: U.S. Geological Survey Water-Supply Paper 8016-20.

SonTek, (1997). Acoustic Doppler Profiler (ADP) Principles of Operation, Technical Notes. San Diego, CA: SonTek Inc., p. 12.

Sontek, (2007). RiverSurveyor System Manual Software Version 4.60: Son-Tek/YSI Inc, Manual, 182 p.

Stone, M. C., Hotchkiss, R. H., (2007). Evaluating velocity measurement techniques in shallow streams. Journal of Hydraulic Research, 45(6), 752-762.

Szupiany, R.N., Amsler M.L., Parsons, D.R. Best, J.L., (2009). Morphology, flow structure, and suspended bed sediment transport at two large braid $\square$ bar confluences. Water Resources Research, 45(5).
Tauro, F., Selker, J., van de Giesen, N., Abrate, T., Uijlenhoet, R., Porfiri, M., Manfreda, S., Caylor, K., Moramarco, T., Benveniste, J., Ciraolo, G., Estes, L., Domeneghetti, A., Perks, M.T., Corbari, C., Rabiei, E., Ravazzani, G., Bogena, H., Harfouche, A., Brocca, L., Maltese, A., Wickert, A., Tarpanelli, A., Good, S., Lopez Alcala, J.M., Petroselli, A., Cudennec, C., Blume, T., Hut, R., Grimaldi, S., 2018. Measurements and Observations in the XXI century (MOXXI): innovation and multi-disciplinarity to sense the hydrological cycle. Hydrol. Sci. J. 63, 169-196. https://doi.org/10.1080/02626667.2017 1420191

Teledyne RD Instruments, (2014). WinRiver II Software User's Guide: P/N 957-6231-00.

Thorne, P. D., Hurther, D., (2014). An overview on the use of backscattered sound for measuring suspended particle size and concentration profiles in non-cohesive inorganic sediment transport studies. Continental Shelf Research, 73, 97-118.

Venditti, J. G., Church M., Attard M. E., Haught D. (2016), Use of ADCPs for suspended sediment transport monitoring: An empirical approach, Water Resour. Res., 52, 2715-2736, DOI:10.1002/2015WR017348.

Vogt, R. H. Neubauer, W.G., (1976). Relationship between acoustic reflection and vibrational modes of elastic spheres. J. Acoust. Soc. Am., vol. 60, No. 1.

Winterwerp, J. C., Wang, Z. B., Van der Kaaij, T., Verelst, K., Bijlsma, A., Meersschaut, Y., Sas, M., (2006). Flow velocity profiles in the Lower Scheldt estuary. Ocean Dynamics, 56(3-4), 284-294.

\section{ADCP, BADANIA PRZEPŁYWU W RZEKACH ZA POMOCA ANALIZ WIELOCZĘSTOTLIWOŚCIOWYCH}

\section{ABSTRAKT}

\section{Cel pracy}

Stosowanie akustycznego dopplerowskiego przepływomierzu profilującego (ADCP) w ostatnim czasie staje się coraz bardziej powszechnie. Ze względu na zastosowanie różnych urządzeń, pojawia się pytanie, czy istnieją różnice w pomiarach ADCP ze względu na wysokość częstotliwości.

Niniejsze badania miały na celu porównanie i ocenę w warunkach polowych trzech urządzeń ADCP działających na różnych częstotliwościach: $2000 \mathrm{kHz}, 1500 \mathrm{kHz}$ i $600 \mathrm{kHz}$.

\section{Materiał i metody}

Dla przekroju poprzecznego o szerokości $100 \mathrm{~m}$ i głębokości $7 \mathrm{~m}$ przyjęto następujące parametry: (1) składowe prędkości przepływu, (2) głębokość, (3) odległość poprzeczną między wektorami, (4) odległość całkowitą i (5) położenie geograficzne każdego wektora. 


\section{Wyniki i wnioski}

Wyniki pokazały, że wielkości prędkości były niskie w obszarach brzegowych, podczas gdy bliżej środka wysokie. W porównaniu z innymi urządzeniami, ADCP o $2000 \mathrm{kHz}$ utrzymuje jednorodny rozkład prędkości do głębokości 5,0 m. Ponadto, statystyczna i graficzna analiza wykazała, że różnice w pomiarach przepływu nie wynosiły więcej niż 5\%. Niemniej jednak zestawienie prędkości wykazało znaczne różnice między urządzeniami ADCP. Wysoka częstotliwość oznacza bardziej szczegółowe dane, lecz także płytszy zasięg, szczególnie w strefach o wyższym stężeniu osadów. Niska częstotliwość oznacza mniej szczegółowe dane, lecz głębszy zasięg. Według naszych badań pomiary wykonywane w rzekach czasem dostarczają zupełnie innych rezultatów niż te przeprowadzone w laboratorium.

Słowa kluczowe: ADCP, pomiar głębokości, przepływ rzeki, hydrodynamika, techniki akustyczne 